\title{
Sinemada Gerçeklik ve Düşsellik / Hakikat ve Yalan
}

\author{
Oğuz ADANIR *
}

Bin beş yüz yıldan uzun bir süre boyunca ne gizemli ne de metafizik düşünce yapısı, sanatsal güzelliğin doğası konusunda modern akılcı düşünce yapısını tatmin edebilecek bir açıklama getirememiştir. Modern dünyanın şekillenmeye başladığı bir dönemde Kant yalnızca duygulara seslenip kişiye verdiği zevkle sınırlı bir sanatsal güzelliğin biliminin yapılamayacağını söylerken, ardından gelen Hegel'in tersini söylemesiyle ortalık kızışmış ve o gün bugündür sanat felsefesi herkesi doyuracak yanıtlar üretmekten görece uzak bir alan olmayı sürdürmüştür.

Gerçekten de bir yandan zevklerin ve renklerin tartışılamayacağı, yani insanda öznel duygular uyandıran bir şeyin, bir nesnenin nesnel açıklamasının yapılamayacağı söylenirken diğer yandan, özellikle son üç yüz yıldır, yani akılcı düşüncenin egemenliğini ilan etmesinden bu yana, sanatsal alanların bir kısmı binlerce yıllık bir geçmişle taçlandırılıp estetik-ahlaki kurallar, toplumsal ve tarihsel, ekonomik, politik ve kültürel koşullar, zihniyet gibi kavramlara başvurularak neredeyse sayısız sanat ve sanatsal güzellik açıklamaları yapılmış ve yapılmaya da devam edilmektedir. 'Sanat felsefesi' başlı̆ı̆ altında yapılacak herhangi bir açıklama, ödünç aldığı ya da kendi belirlediği oyun kuralları çerçevesinde bir başlangıç noktası saptayarak ardından bir sona ulaşmaktadır.

Müzik, şiir, plastik sanatlar gibi alanlarda beğeninin görece daha yoğun duygusal özellikler taşıması nedeniyle çözümleme yapan insanların işi sanki oldukça zorlaşmaktadır. Oysa Arthur Koestler'i izlediğimizde bu alanlarda düş gücü ve yaratıcı düşüncenin akılcı süreçten yine de tamamen kopuk olmadığı ve Jean Lacoste'un deyimiyle dışavurumun bir yalandan ibaret olduğu durumlarda bile sanat eserinin belli bir hakikat payı içerdiği anlaşılmaktadır.

Bizim üstünde duracağımız alanın sinema olması nedeniyle çözümlemenin de görece daha kolay bir şekilde yapılabileceği söylenebilir. Ancak, bu gerçekten de doğru bir saptama mıdır? Öykülü filmleri izleyen insanlar gösteri bittikten sonra genellikle, "çok sevdim, sevdim, hoştu, güzeldi, beğendim, hiç sevmedim, çok kötüydü, çok çirkindi, çok korktum ya da çok sıkıldım, bunaldım" gibi neredeyse hepsinin duygusal olduğu söylenebilecek ifadeler, sözcükler kullanmaktadırlar. Bu durumda bir filmi figüratif bir tablo ya da bir müzik parçasından ayıran özelliğin ne olduğunu söylemek güçleşmektedir. Ancak, değişik sanat alanlarında ortaya çıkan güzelliğin ya da çirkinliğin benzer sözcüklerle dile getirilmesi bu sanat alanlarında gerek yaratıcı gerekse dışavurum süreçlerinin aynı şekilde işlediği anlamına gelmemektedir.

Sanatsal alanların genelinde 'güzel' kavramının göreceliği, aynı nesneyi çirkin olarak nitelendiren bir başka kitlenin varlığını kanıtlamanın yanı sıra, güzelliğin kolay kolay çirkinlikten bağımsız bir şekilde ele alınamadığını da göstermektedir. Ayrıca, bu görecelik, bu iki kavramın öykü, teknik, oyunculuk, plastik, anlatım ve kurgulama, vs düzeyinde ve başarı/başarısızlık kapsamında da ele alınabileceğini gösterir. Günümüzde herhangi bir seyircinin bir film konusundaki beğenisini duygusal ağırlıklı sözcüklerle yansıtması, bu beğeninin sinemaya ve özellikle öykülü filme özgü bütün bu unsurların bir araya getiriliş biçimini de kapsaması gerektiği anlamına gelir. Başka bir deyişle öykülü bir film tamamıyla duygusal olarak nitelendirilebilecek özelliklere sahip olduğunda bile bu duygusallık önce belli bir süre gerektiren öykü/senaryo yazım sürecinde 
oluşturulmaktadır. Bir kez bu süreç sona erdiğinde çekim sürecinde deneyimli bir oyuncu kadrosu ve teknik ekiple yazılı sözcüklere bir can katılmaya ve kurgu, müzik gibi unsurların katılımıyla da izleyicinin duygusal yapısını etkileyecek bir film oluşturulmaya çalışılmaktadır.

Jean Mitry’nin çalışmalarını göz önünde bulundurduğumuzda, öykülü film düzeyinde baştan sona her aşamanın akılcı bir süzgeçten geçtiği ve duygusallığın neredeyse tamamıyla akııcı düşüncenin ürünü olduğu görülmektedir. Burada az önce söylendiği gibi dışavurumun bütünüyle yalandan ibaret olması durumunda bile duyguların gerçekçi bir şekilde dile getirildiği ve öykü yaşamsal anlamda herhangi bir gerçek ya da gerçeklikten söz etmese bile filmin kişiler arasındaki 'duygusal gerçekliği' doğru bir şekilde yansıttığı söylenebilecektir. Bu bir çelişki gibi görünmekle birlikte, çok doğru bir tespittir. Öykülü filmlerde duygular istense de birebir gerçekte olduğu gibi verilemez. Bunun iki nedeni vardır, biri gerçeğe benzer olmak isteyen öykülü bir filmin göstermek istediği duygusal anları filmsel gerçeklik denilen bir çerçeve içinde sunmak zorunda olmasıdır. Başka bir deyişle film önce kendine özgü bir gerçeklik evreni oluşturmak ve bir kez bu işi başardıktan sonra aynı çerçeve içinde duyguların gerçeğe benzer olmasını sağlamakla yükümlüdür, aksi takdirde önemli duygusal sahnelerin birçok (kötü ya da sıradan) filmde karşılaşıldığı gibi komik sahnelere dönüşmesi işten değildir. İkinci nedene gelince, imge gözlerle değil zihinle algılanan bir şeydir. Bir görüntü, bir imge istense de yalnızca gözlerle algılanamamaktadır. Bakan insan gördüğü imgeye kendiliğinden denilebilecek ikincil bir anlam yüklemektedir. Sahip olduğu yaşam deneyimi, bilgi birikimi, bilinç düzeyi bu insanın imgeye görece öznel bir anlam yüklemesine neden olmaktadır. Burada yönetmenin görevi görülen şeyin seyirci tarafından keyfi bir şekilde algılanmasını engelleyip ona kendi bakış açısını kabul ettirip, imgeyi kendi istediği şekilde algılamasını sağlamaktır.

Görüleceği gibi öykülü bir filmde duygusal anların, imgelerin üretimi bizzat gerçekte yaşandıkları şekilde olamamaktadır. Bu duygusal anların gerçekte yaşandığı şekilde çekilmeleri ve sunulmaları durumunda izleyi- ci bunları çoğunlukla yadsımakta ve etkilenmemektedir. Bir bakıma izleyici bu görüntülerin bir yandan sahte görüntüler, yani gerçek kahramanlar değil, o sırada ekranda izlemekten hoşlandığı kahramanlar aracılığıyla yansıtılmasını istemekte ve bu imgeleri görece gerçekçi bularak, üzerinde yarattıkları gerçeklik izlenimi, gerçeklik duygusunu onaylayıp heyecanlanmakta, duygusallaşmaktadır. Öyleyse öykülü sinemaya özgü belli film türleri düzeyinde seyirci açısından önemli olanın imgenin gerçek yaşama özgü bir gerçekçilik değil, kurmacaya özgü yeniden üretilmiş yapay bir gerçeklik evreni içinde kendisini gerçekten duygulandırabilecek kahramanların inandırıcı imgeleri olduğunu söyleyebiliriz. Özellikle melodramlar bu türden filmler olup izleyici bir bakıma kendisini zihinsel açıdan etkileyecek bir öyküden çok duygusal açıdan etkileyip ağlayarak, boşalmasını, vs sağlayacak kahramanlar görmek istemektedir. Bunların yakın plan çekimleri izleyicinin işini kolaylaştırmakta ve yalancı öykünün yalancı kahramanıyla birlikte gerçek gözyaşları dökmesine yol açmaktadır.

Buraya kadar yapılan açıklamalar bizi nedense modern dünyaya ait bireyin, deyim yerindeyse kendisini ezip, hırpalayan ve yalnızlaştıran gerçek yaşamdan kaçmak amacıyla diğerleri arasında oldukça inandırıcı bir yalan söyleme biçimi ya da yöntemi olan sinemayı seçmesi ve filmdeki kahramanların duygularını içtenlikle paylaşması gibi anlaşılması zor bir sonuca götürmektedir.

'Gerçek ve düşsel', 'hakiki ve sahte' gibi modern felsefi düşünce alanına giren kavramların bu bağlamda ele alınması kaçınılmaz hale gelmektedir. Modern birey neden modern yaşamın gerçekliğinden kaçarken onun düşsel versiyonunu kabul edip yansıttığı duyguları birebir paylaşmaktadır. Öte yandan neden imgelerden oluşan bir hakikati kabul edip sahte kahramanların kendisine gerçek duygular yaşatmasını arzulamaktadır.

Bugüne kadar hep içinde yaşanılan toplumsal gerçeklikten bir kaçış aracı olarak nitelendirilen sinema bu bakış açısından ele alındığında insanın aklına acaba hiç böyle bir işleve sahip oldu mu sorusunu getiriyor. Zira gerçekliğin kendisini yadsıyıp imgelerini ve yol açtığı duyguları onay- 
layan bir izleyicinin hakikaten gerçeklikten kaçıp kaçmadığını sorgulamak bir tür zorunluluğa dönüşmektedir. Gerçekliğin ancak bir yalana dönüşmesi koşuluyla kabul gördüğünü mü söylemek gerekiyor? Bunlar başlı başına çok kapsamlı çalışmalar yapılmasını gerektiren türden sorulardır. Umarız genç kuşaklar bu türden sorunlarla da ilgilenir.

Biz konuyu ancak kısa bir makale çerçevesinde ele alabiliyoruz. Başka bir deyişle insanın gerçeği, gerçekleri ya da gerçekliği kabul edebilmesi bunlara düşsel, sahte bir görünüm kazandırılmasına mı bağlıdır? 0 zaman doğruları kabul ettirmek için yalan söylenebileceği, ancak bunun gelişigüzel bir şekilde değil, sinema sanatının oluşturduğu hem teknik-estetik kurallar hem de yazar ve yönetmenlerin gerçekliği sunma biçimiyle doğru orantılı olması gerektiği söylenebilir. Öyleyse gerçeklerle ilgili çok güzel yalanlar söylemek insanların bu gerçekleri daha kolay bir şekilde kabul etmelerini sağlayabilir! Bu doğruysa Hollywood sineması da herhalde bunun en önemli örneklerinden biri sayılabilir. 0 zaman insanlara gerçekleri kabul ettirmenin, bu gerçekleri inandırıcı yalanlara dönüştürmekle mümkün olabileceği söylenebilir. Dünya sinemasında bunun binlerce örneği vardır. Çünkü herkes sinemanın gerçeğin kendisini değil görüntülerini sunduğunu ve bu sunumun gerçeğe ait görünümlerin birebir yeniden üretilmesiyle değil belli bir atmosfer oluşturularak yapıldığını bilir.

Gerçekleri olabilecek en usta yalan söyleme yöntemleriyle ifade etmek etik anlamda bir eleştiri konusu olabilir. Ancak, sinemanın gerçekliğin aynı zamanda hem içinde hem de dışında yer alma özelliği, yani düşsel boyutu estetik ilkelerin ön plana geçmesine yol açmaktadır. Başka bir deyişle gerçeklik evreninde yaşananların birebir aynı şekilde ve hiç değiştirilmeden yeniden üretilip aktarılması, görüntüleri inandırıcılıktan uzaklaştırır. Bu, gerçekliğe ait olayları ve duyguları bir bakıma gerçek dışı kılarken gerçekliğe ait olayların öyküleme mantığı çerçevesinde ele alınıp sinematografik teknik ve estetik kurallara boyun eğilerek, kurmaca olarak yeniden üretilmesi aynı olaylar ve duyguların hem düşsel hem de gerçek bir şekilde algı- lanmasına yol açmaktadır. İzleyici ancak bu koşulla içinde yaşadığı gerçekliğin ağırlığına tahammül edebilmekte ya da onu görece kabul etmektedir.

Öte yandan sinemanın gerçek değil düşsel bir olgu olması, onun ahlaki açıdan mahkum edilmesini görece engellemektedir. Çünkü ahlak gerçeklik evrenine ait davranışlar bütünüdür. Oysa bir öykü anlatım biçimi olan sinema imgelerden oluşmaktadır. Sinemada olsa olsa düşsel kahramanların ahlaklı ya da ahlaksızca davranışlarından söz edilebilir. Buna karşın filmin oyun kuralları olduğu, gerçekleri tamamıyla dönüştürerek sunduğunda bile ikna edici olması koşuluyla seyircinin bu kandırmacaya izin verdiği ve bu işi bu kadar iyi kıvırdığı için filmi ve çalışanlarını bağışlayıp, alkışladığı söylenebilir. Çünkü yukarıda sunulan çerçeve içinde gerçekler konusunda iyi yalan söylemeyi beceremeyen filmler seyirci tarafından bağışlanmamakta ve işi ellerine yüzlerine bulaştırdıkları söylenmektedir. Dolayısıyla kötü filmler gerçekleri gerçeklere en yakın şekilde sunsalar bile, belki istisnalar dışında, başarılı sayılmamaktadırlar. Sanat felsefesi sanatsal güzellik ve çirkinliğin doğal güzellik ya da çirkinlikten ayrı bir şekilde değerlendirilmesi gerektiğini, bu sonuncuların kendi ilgi alanı içine girmediğini söylemektedir.

Sonuç olarak belli sinematografik türler sanki belli bir gerçeklik evrenine özgü çirkinlikleri hem biçimsel hem de içerik düzeyinde belli ölçüde değişikliğe uğratarak ya da dönüştürerek yansıttıklarında, yani sanatsal niteliğe sahip bir güzellik ya da çirkinlik kavramı içine oturttuklarında insanın ruhsal yapısını daha derinden etkileyebilmektedirler. Başta da söylendiği gibi, güzelliğin çirkinlik olmadan kavranması zor göründügünden bu tür filmlerde çirkinlik ve güzellik karşılıklı olarak birbirlerini içermekte ve birbirlerine hizmet etmektedirler. Görünüşe göre bütün bu süreçten kazançlı çıkabilecek biri varsa o da anlatılan ya da gösterilenlerden kendince ders çıkaracak izleyicidir. Sinema toplumsal yaşamı değiştiremez ama insanlara değişik ve düşsel toplumsal yaşam örnekleri sunabilir. Bu da dünyanın değişmesine kendince bir katkıda bulunma anlamına gelebilir. 